\title{
Strongyloides stercoralis found in imported dogs, household dogs and kennel dogs in Iceland
}

\author{
Matthías Eydal and Karl Skírnisson \\ Institute for Experimental Pathology at Keldur, University of Iceland, Keldnavegur 3, IS-112, Reykjavik, Iceland \\ E-mail:meydal@hi.is,karlsk@hi.is
}

\begin{abstract}
The aim of this paper is to report cases of the intestinal parasitic nematode Strongyloides stercoralis in dogs in Iceland. The nematode was diagnosed in $20(0.6 \%)$ of imported dogs in quaratine in Iceland during 19892016. Household dogs: The first case of S. stercoralis infection diagnosed outside quaratine in Iceland was in an unhealthy household puppy purchased from an Icelandic breeding kennel (Kennel A) in 2012. A total of nine puppies purchased from Kennel A, and two dogs which had contact with dogs from the kennel, were diagnosed with S. stercoralis. Kennel dogs: In 2012 S. stercoralis was confirmed in dozens of dogs in Kennel A. Follow-up examinations after anthelmintic treatments indicated a successful removal of worms in imported and household dogs. In spite of more than a dozen anthelmintic treatment actions and other arrangements in Kennel A since 2012, recurrent infections have repeatedly been confirmed, the last one in 2015 . The nematode is believed to have been introduced to the breeding kennel with an imported dog, in spite of anthelmintic treatments in quarantine.
\end{abstract}

\section{YFIRLIT}

Sníkjupráðormurinn Strongyloides stercoralis staðfestur á Íslandi í innfluttum hundum, heimilishundum og í hundaræktunarstöð.

Markmið pessa yfirlits er að greina frá tilfellum sem greinst hafa af sníkjupráðorminum Strongyloides stercoralis í hundum á Íslandi. Ormurinn hefur greinst í saursýnum úr 20 (0.6\%) hundum sem fluttir voru til landins um einungrunarstöðvar á árunum 1989-2016. Heimilishundar: Fyrsta tilfelli utan einangrunarstöðva greindist í veikum heimilishvolpi sem keyptur var á íslenskri hundaræktunarstöð 2012. Ormurinn greindist í alls níu hvolpum sem keyptir voru á stöðinni og í tveimur heimilishundum sem höfðu haft samgang við hunda frá stöðinni. Hundaræktunarstöðin: S. stercoralis greindist í tugum hunda í stöðinni í byrjun árs 2012, bæði í hvolpum og fullorðnum hundum. Innfluttu hundarnir og heimilishundarnir fengu ormalyfjameðferð og eftirfylgnirannsóknir bentu til að tekist hefði að uppræta ormana. Margendurteknar ormalyfjagjafir á árunum 2012 -2016 og aðrar aðgerðir í hundaræktunarstöðinni virðast hafa borið umtalsverðan árangur en ormurinn hefur pó greinst í stökum saursýnum á undanförnum árum, síðast í nóvember 2015. Talið er að práðormurinn hafi borist inn í hundaræktunarstöðina með innfluttum hundi, prátt fyrir endurteknar ormalyfjagjafir í einangrunarstöð, smitast milli hunda í ræktunarstöðinni og borist paðan út með seldum hundum.

Key words: Dogs, Iceland, infection, nematode parasite, quarantine, Strongyloides stercoralis 


\section{INTRODUCTION}

Strongyloides stercoralis is a soil transmitted intestinal nematode, primarily known as a parasite in humans and dogs (Shoop et al. 2002), but also found in non-human primates and cats (Grove 1996, Júnior et al. 2006) causing the disease strongyloidosis (Goncalves et al. 2007, Requena-Méndez et al. 2013). The life cycle is complex and involves both a freeliving developmental cycle and a parasitic life cycle (Shoop et al. 2002, Bowman 2009), and autoinfection can occur within the host (Olsen et al. 2009). First stage larvae are passed in faeces to the environment. The main route of transmission is by penetration of infective third stage larvae through the skin, and by oral ingestion (Beaver et al. 1984); transmammary transmission in dogs is also possible (Shoop et al. 2002).

S. stercoralis occurs almost worldwide. It is endemic in humid tropical and subtropical regions with the highest concentrations in tropical regions of Africa, South-East Asia and Latin America (Schär et al. 2013). The nematode is also found in temperate regions such as in Europe, in particular in Eastern Europe, and in southern areas of the USA and in Japan (Olsen et al. 2009).

S. stercoralis is a zoonotic parasite (Bowman 2009), i.e. can be transmitted from dogs to humans and vice versa. Although natural transmission from dog to man is rarely reported (Georgi \& Sprinkle 1974) dogs have been successfully infected experimentally with $S$. stercoralis originating from humans (Dawkins \& Grove 1982, Grove \& Northern 1982).

S. stercoralis is most commonly diagnosed by searching for the first stage larvae in faeces, using methods such as the formalin-ethyl acetate sedimentation technique (FEAST) (Allen \& Ridley 1970, Young et al. 1979) and the more sensitive Baermann technique, which is recommended (Dreyer et al. 1996, Krolewiecki et al. 2013, Requena-Mendez et al. 2013).

S. stercoralis has never been suspected to be indigenous in humans in Iceland, the few persons diagnosed to host the parasite having acquired the infection abroad (Richter et al. 1990,
Skirnisson et al. 2003, Ingibjörg Hilmarsdóttir, pers. comm.). A parasitological survey of dogs in Iceland (Richter \& Elmarsdóttir 1997), and examinations of faecal samples from dozens of dogs in past decades (unpublished data), did not reveal $S$. stercoralis infections.

Until the late 1980s a ban on importing dogs into Iceland had been in force for several decades (Anonymous 1947, Pálsson 1984, Runólfsson 2004). The ban was lifted in 1989, with conditions that enforce a stay in quarantine and demand different medical treatments and examinations of dogs, both prior to import into Iceland and during a quaratine period. Since 1989 thousands of dogs have been imported into Iceland from dozens of countries around the world. Consequently, the risk of importing infectious agents not indigenous to Iceland has increased.

The aim of the article is to give an overview over S. stercoralis cases that have been diagnosed in imported dogs in quaratine in Iceland, describe its presence in a local breeding kennel and report cases outside the kennel in dogs that had been bought from the kennel or had interconnection with dogs coming from the kennel. Actions which have been taken to eliminate the parasite and the success of the eradication measures performed in the country are discussed.

\section{MATERIAL AND METHODS \\ Imported dogs in quarantine}

\section{Number and origin of imported dogs}

From 1989 until May 2016 altogether 3208 dogs have been imported into Iceland. The dogs came from 47 countries on six continents; Europe, N America, S America, Australia, Asia and Africa. Most of them had been imported from European countries, approximately one fifth from $\mathrm{N}$ America, and relatively few from other continents. Almost half of the dogs had been imported from the neighbouring Nordic countries: Denmark, Norway, Sweden and Finland.

\section{Quarantine and duration of stay}

According to Icelandic legistion all imported 
dogs must be quarantined. Since 1989 two quarantine stations have operated in Iceland, one on Hrísey in N Iceland (not operating in 2007, closed down in 2015), another, established in 2005, in Hafnir, SW Iceland. During 1989-2003 dogs were kept in quarantine for 6-12 weeks, but since 2004 the quarantine period has been 4 weeks.

\section{Treatment against parasites}

A part of the requirements for the importation of dogs to Iceland, issued by the Icelandic Food and Veterinary Authority, is treatment against cestodes (Echinococcus spp.), within 10 days before importing. No specific treatment against nematodes is obligated.

In the quarantine stations procedures concerning anthelmintic treatments and the choice of drugs have varied in the past. Currently, all dogs are treated twice against cestodes and nematodes; first immediately after arrival in the station when a faecal sample has been collected; again at the end of the quarantine period. At present the anthelmintic drug used is a mixture of praziquantel, pyrantel and febantel (Prazitel Plus ${ }^{\circledR}$ ). A mixture of imidacloprid and moxidectin (Advocate $\AA$ ), used against ectoparasites, which is also an antinematodal drug, is also applied, both at the onset and at the end of the quarantine period.

In cases when $S$. stercoralis has been diagnosed an additional anthelmintic treatment is performed. This includes one subcutaneous injection with ivermectin (Ivomec ${ }^{\circledR}$ ) followed by administering fenbendazole (Panacur ${ }^{\circledR}$ ) for seven consecutive days.

\section{Search for parasites}

According to regulations issued by the Icelandic Food and Veterinary Authority, faecal samples from imported dogs are subjected to examination for the presence of intestinal parasites. During 1989-2003 two faecal samples were examined from each dog, the first sample taken after arrival in the quarantine, before anthelmintic treatment; the second one taken at the end of the quarantine period, after the treatment. After shortening the quaratinized period to four weeks in 2004 a single faecal sample, taken prior to anthelmintic treatments, has been examined from each dog.

All faecal samples collected in quarantine stations have been examined by using the formalin-ethyl acetate sedimentation technique (FEAST), a method used to concentrate protozoan cysts, coccidian oocysts, helminth eggs and larvae (including S. stercoralis) (Allen \& Ridley 1970, Young et al. 1979). For this pupose the Faecal Parasite Concentrator (FPC $®)$ kit from Evergreen Scientific has been used. Since March 2012, all samples collected from dogs in quarantine stations have also been examined using a modified Baermann technique, a method based on the description of Henriksen (1965). Preferably 25-30 $\mathrm{g}$ fresh faeces is wrapped in a double (in the case of soft stool into a triple) layer of cheesecloth (absorbent gauze in rolls, Mullro ${ }^{\circledR}$ ) and submerged into a $375 \mathrm{ml}$ conical "Baermann" glass filled with approximately $300 \mathrm{ml}$ of tap water (Figure 1). The sample is kept completely immersed in the water for 7-24 hours (usually overnight) at room temperature. Upon examination all sediment from the bottom of the glass is pipetted, put on one or more microscope slides, mixed there with a drop of iodine, and screened at $62.5 \mathrm{x}$ magnification in a light microscope for $S$. stercoralis first stage larvae (L1).

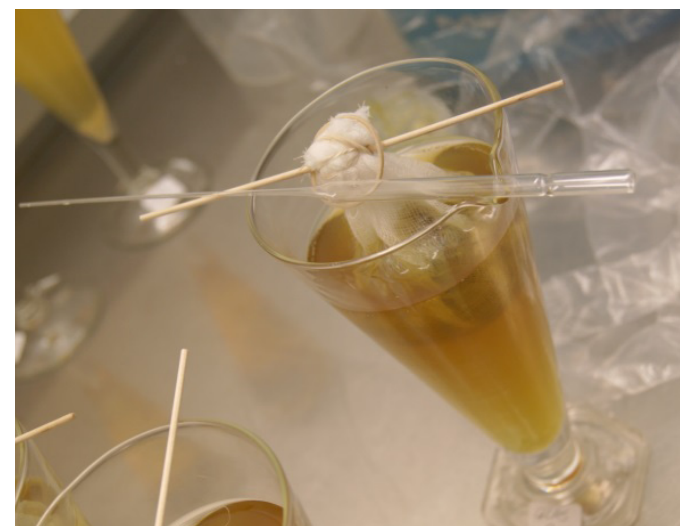

Figure 1. Photograph showing a conical Baermann glass with faeces wrapped in cheesecloth, submerged in $300 \mathrm{ml}$ of tap water. On the top of the glass there is a $225 \mathrm{~mm}$ long Pasteur pipette used to obtain Strongyloides stercoralis larvae from the bottom of the glass. 
If $S$. stercoralis was diagnosed in a dog in a quarantine station (Table 1) follow-up examinations were performed. After the initial anthelmintic treatment faecal samples were examined three times with the Baermann method; at the end of the quarantine period, and then again one month and four months after the dog had been delivered to the owner. Each time faeces were collected on three consecutive days and a pooled sample examined.

\section{Household dogs}

S. stercoralis was confirmed for the first time in an Icelandic household dog in February 2012. The infected dog had been purchased from a breeding kennel (hereafter Kennel A) operating in SW Iceland (see below), indicating the presence of the nematode in dogs in the kennel. Since 2012 faecal samples from a total of 42 puppies purchased from Kennel A have been examined for the presence of $S$. stercoralis larvae. Fifty-four additional dogs, many of them having some history of interconnection with dogs originating from Kennel A, have also been examined. In all cases the Baermann technique was used, with the exception of the first case that was detected using the FEAST method.

Icelandic household dogs diagnosed to be infected with $S$. stercoralis have received anthelmintic treatments. According to our best information, a treatment with fenbendazole, for at least five consecutive days, has been carried out in all cases. As a rule, one or more follow-up examinations have also been carried out, usually one month, and again three to four months after the first treatment. Each time three faecal samples, taken on three consecutive days, have been examined. In one case, however, the owner did not send in faeces for a follow-up study.

\section{Dogs in breeding Kennel $A$}

Kennel A was established in 1998, with the aim to breed and sell pure-bred puppies. When importation of dogs to the kennel discontinued some years ago, altogether 135 dogs had been imported. The kennel, however, continued breeding and selling dogs. Most of the dogs $(42 \%)$ were imported from breeders in Denmark and $36 \%$ came from different breeders in the USA. The remaining 30 dogs were imported from 11 other countries, most of them in Europe. A few dogs originated from S America and Australia.

In February 2012 approximately 200 different-aged puppies and adult dogs of various breeds lived in Kennel A. After confirming the S. stercoralis infection in a puppy that was recently purchased from the kennel (Table 2) a systematic search for the parasite was carried out (Table 3). Since this initial examination 13 additional examinations have been performed (Table 3). On each occasion the owners collected faecal samples from the floor in the separate pens or sections of the kennel (usually approximately five grams from each faeces) and pooled them (on the first occasions advised and helped by veterinarians from the Icelandic Food and Veterinary Authority). Usually the pooled samples consisted of faeces from 3-10 different dogs, in some cases samples were taken from indiviual dogs. Each sample was labeled with the pen name and names or breeds of the respective dogs.

The Baermann technique was used to search for nematode larvae in the samples. Usually approximately $30 \mathrm{~g}$ of a pooled faecal sample were used for each Baermann glass; in case of larger samples, faeces were divided into two, sometimes three portions, in order to check all faeces sent in for the presence of $S$. stercoralis larvae.

Immediately after confirming the $S$. stercoralis infection in Kennel A, the Icelandic Food and Veterinary Authority organised anthelmintic treatment of all dogs in the kennel, and also suggested some actions for the purpose of eradicating the parasite, measures that included, for example, cleaning and disinfection. The first treatment was performed in March 2012. Since then the owners claim that all dogs in the Kennel have regularily been treated using the anthelmintic fenbendazole (Table 3). Each time the drug has been administered for five consecutive days, and 2-3 weeks later the treatment has been repeated. Newborn puppies have not been treated. 


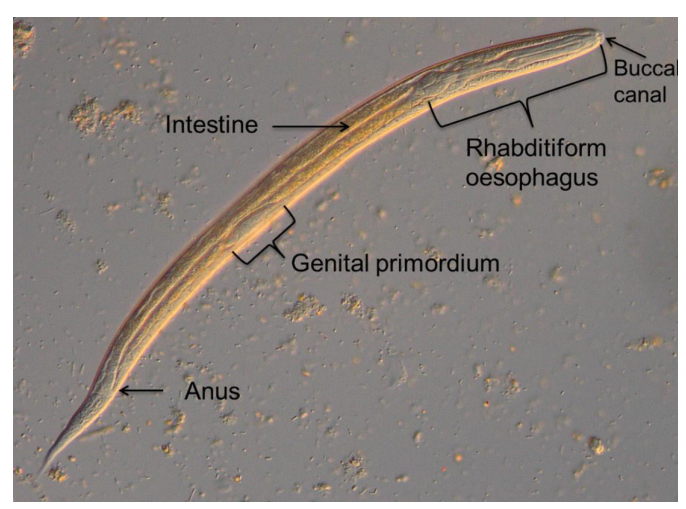

Figure 2. Light microscope photograph of a $371 \mu \mathrm{m}$ long, iodine-stained Strongyloides stercoralis first stage larva from freshly passed dog faeces. The most important morphological characteristics used to identify the species are pointed out.

\section{Parasite identification, measurements and photography}

Identification of $S$. stercoralis first stage larvae (Figure 2) was based on morphological descriptions presented by Little (1966), Beaver et al. (1984), Miyazaki (1991) and Ash \& Orihel (1997). Microscopical size dimensions of fresh first stage larvae were obtained using a calibrated eyepiece scale. Altogether, 52 larvae obtained from 14 separate (individual or pooled) faecal samples were measured.

The photograph of the larva presented in Figure 2 was taken with a Nikon DS-Vi1 digital camera attached to a Leica DMLB microscope, equipped for differential interference contrast microscopy (DIC; Nomarski).

\section{RESULTS}

\section{Imported dogs in quarantine}

Altogether $20(0.6 \%)$ out of 3208 dogs imported into Iceland have been diagnosed as infected with S. stercoralis since 1989 (Table 1). The first two cases were young puppies imported from Europe in 1994, and the remaining 18 dogs were imported in more recent years (20082015). Most of the infected dogs (18) came from different countires of Europe (seven from Sweden, four from Hungary, two from Belgium and one each from Finland, Poland, Latvia,
Russia and the UK); two had been imported from the USA.

One of the two infected dogs originating from the USA was imported by the owners of Kennel $A$ in 2008. In this case a follow-up examination 10 days after anthelmintic treatment, using the FEAST method, did not reveal the parasite. Further follow-up studies were not performed.

Dogs infected with $S$. stercoralis were of 12 different breeds (Table 1). Seventeen of them $(85 \%)$ were puppies or young dogs (aged 5-18 months); three (15\%) were older (aged $2-7$ years); the infected adult dogs were imported in recent years (2014-2015) (Table 1).

The eight $S$. stercoralis cases diagnosed during 1989-2011 were detected by using the FEAST method, the only technique used during the period. After also introducing as a routine method the more sensitive Baermann technique in 2012, a total of 12 cases have been detected; nine of the cases were solely diagnosed by the Baermann method, one by the FEAST method, and two were detected by both methods.

Follow-up studies of dogs diagnosed as infected with $S$. stercoralis in quarantine have never revealed infections after treatment.

\section{Household dogs}

In total 11 household dogs in Iceland were diagnosed as infected with $S$. stercoralis (Table 2). The first case was a diseased five-month old puppy purchased from Kennel A in February 2012. Eight additional household dogs were found to be infected in 2012 and 2013; a single case was detected in February 2014, and the last case was diagnosed in January 2015. Since then (now 20 months later) no infected household dogs have been diagnosed in Iceland.

Nine of the 11 infected dogs were born and raised in Kennel $\mathrm{A}$ and purchased as puppies from there. The remaining two were adult bitches. One of them had been in contact with dogs coming from the kennel but further details are unknown. The other bitch lived in the same home as the puppy which was first diagnosed as infected with S. stercoralis (Table 2). This puppy was abnormally small, having diarrhoea and mucus and blood in the faeces. Another 
Table 1. Twenty dogs found to be infected with Strongyloides stercoralis by examination of faecal samples from 3207 quarantined dogs imported to Iceland during the period from 1989 to May 2016.

\begin{tabular}{|c|c|c|c|}
\hline Date of import & Country of origin & Breed & Age \\
\hline 8 June 1994 & Belgium & Yorkshire terrier & 5 months \\
\hline 8 June 1994 & Belgium & Yorkshire terrier & 5 months \\
\hline 15 April 2008 & Hungary & King Charles spaniel & 9 months \\
\hline 20 May 2008 & USA & Maltese & 18 months \\
\hline 15 July 2009 & Sweden & Boston terrier & 5 months \\
\hline 9 February 2010 & USA & Pomeranian & $7 \frac{1}{2}$ months \\
\hline 20 December 2010 & Finland & Chihuahua & 6 months \\
\hline 10 May 2011 & Sweden & Pomeranian & 8 months \\
\hline 25 April 2012 & Sweden & Toy poodle & $51 / 2$ months \\
\hline 13 March 2013 & Sweden & Pomeranian & 13 months \\
\hline 25 March 2013 & Poland & Pug & 7 months \\
\hline 8 October 2013 & UK & Papillon & 12 months \\
\hline 1 April 2014 & Hungary & French bulldog & $71 / 2$ months \\
\hline 1 April 2014 & Hungary & French bulldog & $101 / 2$ months \\
\hline 1 December 2014 & Sweden & Dachshund & 7 years \\
\hline 7 January 2015 & Sweden & Poodle & 18 months \\
\hline 7 January 2015 & Sweden & Poodle & $51 / 2$ years \\
\hline 28 January 2015 & Russia & Pomeranian & 2 years \\
\hline 5 August 2015 & Latvia & Yorkshire terrier & 11 months \\
\hline 11 November 2015 & Hungary & French bulldog & 7 months \\
\hline
\end{tabular}

puppy was also observed to have blood in the faeces, three other puppies had diarrhoea and one had soft stool (Table 2). Thus, at least six of the 11 houshold dogs showed some clinical symptoms which might have been associated with the $S$. stercoralis infection (Table 2).

The number of larvae recovered from the dogs varied considerably (Table 2). The highest number recovered was approximately 6000 larvae from a $6 \mathrm{~g}$ sample, representing approximately 1000 larvae per gram of faeces. In approximately half of the remaining samples hundreds of larvae (129-500) were recovered and counted on the microscopical slides, but in four cases only 3-12 larvae were found per sample (Table 2). In the case of the puppy first found to be infected (see above), ten larvae per slide examined by the FEAST method indicated a high abundance of larvae in the faeces.

Follow-up studies after anthelmintic treatment (1-3 sampling dates, 1-6 months post treatment) did not reveal $S$. stercoralis larvae except in samples from two dogs where anthelmintic treatment had to be repeated. However, continued follow-up studies in both cases indicated that the infections were successfully eliminated.

\section{Dogs in breeding Kennel A}

Since the confirmation of $S$. stercoralis infection in Kennel A in February 2012 faecal samples have been examined on 13 occasions; usually twice a year, but up to five times per year (in 2014); in total nine anthelmintic treatment actions have been registered (Table 3 ). The initial examination indicated a widespread S. stercoralis infection; half of the examined samples revealed the parasite. A few months later, in April and May 2012, following anthelmintic treatments, the parasite was not 
Table 2. Household dogs (outside of Kennel A) in Iceland during 2012 to May 2016 confirmed by faecal examination to be infected with Strongyloides stercoralis.

\begin{tabular}{lllccl}
\hline $\begin{array}{l}\text { Month and year } \\
\text { of diagnosis }\end{array}$ & Dog breed & Age & $\begin{array}{c}\text { Originating } \\
\text { from Kennel A. }\end{array}$ & $\begin{array}{c}\text { Number of first } \\
\text { stage larvae }\end{array}$ & Clinical symptons \\
\hline February 2012 & Cavalier & 5 mo & yes & $10^{*}$ & $\begin{array}{l}\text { Abnormally small, } \\
\text { bloody mucoid } \\
\text { diarrhoea }\end{array}$ \\
February 2012 & Japanese Chin & $5 \mathrm{yr}$ & no & 3 & None \\
February 2012 & Cavalier & $3 \mathrm{mo}$ & yes & 220 & None \\
March 2012 & Cavalier & $7 \mathrm{mo}$ & yes & 15 & Not mentioned \\
April 2012 & Dachshund & $5 \mathrm{yr}$ & no & 12 & Not mentioned \\
January 2013 & King Charles spaniel & $7 \mathrm{mo}$ & yes & many & Blood in faeces \\
January 2013 & Golder retriever & $5 \mathrm{mo}$ & yes & 500 & Soft stool \\
August 2013 & Cavalier & $6 \mathrm{mo}$ & yes & 169 & Diarrhoea \\
Sept. 2013 & Pomeranian & $6 \mathrm{mo}$ & yes & 129 & Diarrhoea \\
February 2014 & Coton de Tulear & $6 \mathrm{mo}$ & yes & 6000 & None \\
January 2015 & French bulldog & $2 \frac{1}{2}$ mo & yes & 3 & Diarrhoea \\
\hline
\end{tabular}

"Number of larvae per slide examined by the the formalin-ethyl acetate sedimentation technique. The other values represent total number of larvae recovered per Baermann glass

detected. However, two examinations the next year (February and August 2013) both confirmed the presence of the parasite in separate pens in the kennel. In 2014 the parasite was not detected in March, May, July and August, but then S. stercoralis larvae were found in two pooled samples in December 2014. In 2015 no infection was detected in April, though one sample in November still confirmed the presence of the parasite in Kennel A. In the most recent examination (May 2016) the parasite was not detected (Table 3).

\section{Measurements of larvae}

The average length of fresh $S$. stercoralis larvae (Figure 2) from 14 faecal samples measured 345 $\mu \mathrm{m}(\mathrm{SD} \pm 37.9 \mu \mathrm{m}$, range $260-422 \mu \mathrm{m}, \mathrm{n}=52)$.

\section{DISCUSSION}

Importation of dogs to Iceland was banned in 1909 as a measure to prevent the reintroduction of the adult stage of Echinococcus granulosus, the causative agent of the widespread and serious hydatid disease (Pálsson 1984). As the ban was lifted 80 years later relatively few dogs, only a few thousands, were estimated to live in the country. Since the ban was lifted in 1989 thousands of dogs have been imported; in total 608 during 1989-2000; after that on average of approximately 170 dogs per year. At present dogs are quite commonly kept in Icelandic households.

Until May 2016 altogether 20 dogs had been diagnosed as having $S$. stercoralis infections upon arrival at quarantine stations in Iceland. The first two dogs were diagnosed in 1994 but fourteen years passed until the parasite was confirmed again in an imported dog. Most of these dogs (18) came from Eureopean countries; two came from the USA.

The first dog diagnosed as infected with $S$. stercoralis outside quarantine stations in Iceland was a diseased puppy purchased in February 2012 from the breeding Kennel A. At this time more than 100 dogs had been imported through quarantine to the kennel, including a dog originating from a breeder in the USA in spring 2008 that was found to be infected with $S$. stercoralis upon arrival at the quarantine station in Iceland. After routine anthelmintic treatment a single follow-up examination performed with the FEAST method did not reveal any $S$. 
Table 3. The presence of Strongyloides stercoralis first stage larvae in faecal samples collected on 14 occasions during 2012-2016 from dogs in the breeding Kennel A in Iceland, presented as proportions (\%) of positive samples. The method used was a modified Baermann technique. Information is given on the timing of anthelmintic treatments.

\begin{tabular}{|c|c|c|c|}
\hline Sampling and treatment dates & $\begin{array}{l}\text { Number of faecal } \\
\text { samples }\end{array}$ & $\begin{array}{l}\text { Positive for } \\
\text { S. stercoralis }\end{array}$ & $\begin{array}{l}\text { Age group infected } \\
(\%)\end{array}$ \\
\hline \multicolumn{4}{|c|}{ ons } \\
\hline \multirow[t]{2}{*}{ February 2012} & 15 pooled samples & 47 & Adults and puppies \\
\hline & 2 individual samples & 50 & Adult \\
\hline \multicolumn{4}{|l|}{ March 2012 - Anthelmintic treatments } \\
\hline April 2012 & 10 pooled samples & 0 & \\
\hline May 2012 & 3 pooled samples & 0 & \\
\hline \multicolumn{4}{|l|}{2013} \\
\hline February 2013 & 6 pooled samples & 17 & Puppies \\
\hline \multicolumn{4}{|l|}{$\begin{array}{l}\text { February/March } 2013 \text { - Anthelmintic } \\
\text { treatments }\end{array}$} \\
\hline \multirow[t]{2}{*}{ August 2013} & 9 pooled samples & 22 & Adults and puppies \\
\hline & 1 individual sample & 0 & \\
\hline \multicolumn{4}{|l|}{$\begin{array}{l}\text { September } 2013 \text { - Anthelmintic } \\
\text { treatments }\end{array}$} \\
\hline \multicolumn{4}{|l|}{2014} \\
\hline March 2014 & 3 pooled samples & 0 & \\
\hline \multicolumn{4}{|l|}{$\begin{array}{l}\text { March/April } 2014-\text { Anthelmintic } \\
\text { treatments }\end{array}$} \\
\hline May 2014 & 8 pooled samples & 0 & \\
\hline July 2014 & 5 pooled samples & 0 & \\
\hline August 2014 & 29 pooled samples & 0 & \\
\hline \multicolumn{4}{|l|}{$\begin{array}{l}\text { August/Sept. } 2014-\text { Anthelmintic } \\
\text { treatments }\end{array}$} \\
\hline December 2014 & 8 pooled samples & 25 & Adults and puppies \\
\hline \multicolumn{4}{|l|}{$\begin{array}{l}\text { December } 2014 \text { - Anthelmintic } \\
\text { treatments }\end{array}$} \\
\hline \multicolumn{4}{|l|}{2015} \\
\hline April 2015 & 7 pooled samples & 0 & \\
\hline \multicolumn{4}{|l|}{ April 2015 - Anthelmintic treatments } \\
\hline November 2015 & 6 pooled samples & 17 & Adults and puppies \\
\hline November 2015 & 14 pooled samples & 0 & \\
\hline \multicolumn{4}{|l|}{$\begin{array}{l}\text { November } 2015 \text { - Anthelmintic } \\
\text { treatments }\end{array}$} \\
\hline \multicolumn{4}{|l|}{2016} \\
\hline May 2016 & 4 pooled samples & 0 & \\
\hline May 2016 - Anthelmintic treatments & & & \\
\hline
\end{tabular}

stercoralis larvae in this dog. Subsequently, the dog was brought to Kennel A, and no further follow-up studies were made. Because an $S$. stercoralis infection may go unnoticed by faecal examination it can not be ruled out that this dog, or some other $\operatorname{dog}$ (or dogs), imported to the 
kennel through quarantine with an unnoticed infection may have been the source of the initial introduction of $S$. stercoralis into the kennel. Furthermore, it is likely that some years passed from the initial introduction of $S$. stercoralis into the kennel until its presence was confirmed in February 2012. This view is supported by the fact that by then every second faecal sample examined from dogs kept in different pens in various parts of the kennel had S. stercoralis larvae.

In general, the results of the present study have confirmed that $S$. stercoralis is able to complete its life cycle and effectively spread under conditions that prevail in an Icelandic breeding kennel. Also, the fact that two adult indigenous dogs with a history of an interconnection with infected dogs from Kennel A (Table 2) had acquired the infection indicates the transmission of S. stercoralis outside of the kennel in Iceland. One of those dogs lived in the same home as the infected puppy diagnosed with S. stercoralis infection in February 2012 (Table 2); the other had stayed for a few days at a home where dogs lived that had a history of interconnection with dogs from Kennel A.

As already described, all dogs found to be infected with $S$. stercoralis in Icelandic quarantine, and those diagnosed in Icelandic households, were specifically treated with the anthelmintic compound fenbendazole. Follow-up examinations indicated that this treatment method successfully eliminated the S. stercoralis infections. However, in two of the household dogs treatment had to be further continued because larvae were still found in faeces after the initial treatment. In these cases it is not known whether the reappearance of larvae in faeces was because of the inadequacy of the anthelmintic compound used or the result of a reinfection.

The results of the present study also emphasise the difficulties in eradicating $S$. stercoralis in Kennel A. Already a few months after the first anthelmintic treatments most infections seemed to have been eliminated, as indicated by faecal examinations. Altogether 13 follow-up studies performed in the past 50 months confirmed, however, that one or more infected dogs were still present in the kennel 12 , 18,33 and 44 months after the first treatment (Table 3).

Various surveys and reports are available on the occurrence of Strongyloides spp. in dogs around the world. There are only two papers that report $S$. stercoralis infections in dogs in the Nordic countries: Dillard et al (2007) described the infection in a kennel in Finland; one puppy suffered from gastrointestinal disturbance and subsequently died; Hamnes et al. (2009) reported the nematode in three puppies with diarrhoea in Norway, one had been bought at a petrol station in Sweden, the others were raised in a local kennel. In the present study one of the infected dogs imported into Iceland came from Finland. However, none of the altogether 214 dogs imported since 2008 from Norway into Iceland were found to be infected. Interestingly, seven of the infected dogs in Iceland originated from Sweden, but no reports are known to the authors that confirm $S$. stercoralis infections in dogs in Sweden. Since 2008 altogether 240 dogs have been imported from Denmark into Iceland, but none have been found to be infected with $S$. stercoralis. In Denmark, no $S$. stercoralis infections were found in 181 hunting dogs examined by Al-Sabi et al. (2013) and in the Faroe Islands no infections were found in 227 dogs examined by Petersen et al. (2008).

Further south in Europe the nematode has been reported from dogs in Ukraine, Poland, France, Romania and Hungary (Taylor et al. 2007), Italy (Stancampiano et al. 2011) and Greece (Papazahariadou et al. 2007). Imported dogs in Iceland from this part of Europe that have been diagnosed with $S$. stercoralis originated from the following six countries: Russia, Latvia, Poland, Hungary, Belgium and UK.

In South America infections in dogs have been reported in Brazil (Júnior et al. 2006, Goncalves et al. 2007) and Venezuela (Strongyloides spp.) (Ramírez-Barrios et al. 2004); in Africa in Ethiopia (Zewdu et al. 2010, Jones et al. 2011) and Nigeria (S. stercoralis and Strongyloides sp.) (Ugochukwu \& Ejimadu 1985, Ugbomoiko et al. 2008); in Asia in Iran 
(Razmi 2009), South Korea (Yang et al. 2013) and Japan (Itoh et al. 2003, Asano et al. 2004, Itoh et al. 2009); and in Australia (Bugg et al. 1999). Focusing on the cases so far diagnosed in Iceland none originated from this part of the world, but it should be noted that relatively few dogs brought to Iceland originated in these geographical areas.

As mentioned, two of the imported dogs found to be infected with $S$. stercoralis came from the USA. In northern areas of the Nearctic Strongyloides spp. have been reported in dogs in Saskatchewan in Canada (Gaunt \& Carr 2011). Finally, S. stercoralis has been reported from the arctic fox (Vulpes lagopus) in Greenland (Kapel $\&$ Nansen 1996). To the best knowledge of the authors the nematode has not been detected in other surveys on this host.

The number of dogs imported into Iceland found to be infected with $S$. stercoralis has increased in recent years: In 2015 five cases were detected in quarantined dogs; in 2014 and 2013 three cases were confirmed each year, but during 2008 - 2012 only seven cases were diagnosed in total. No infected dogs were detected during 1995 to 2007 and the only cases prior to this period were the two cases reported in 1994 (Table 1). One reason for this increase in diagnosed cases might be an increased prevalence of infection in kennels or households abroad where Icelandic dog owners have been purchasing dogs during this period, e.g. in Sweden, in spite of the fact that so far there are no reports of dogs being infected with $S$. stercoralis there. This may emphasise that there is a need for more studies regarding the occurrence of S. stercoralis infections in dogs in general.

The decision to also start using the more sensitive Baermann technique in February 2012, in addition to the FEAST method, to search for S. stercoralis larvae has probably contributed to an increased detection rate of the parasite. The Baermann technique is considered to be among the most reliable parasitological methods used to detect $S$. stercoralis larvae and considerably more sensitive than the FEAST method (Assefa et al. 1991; Buonfrate 2015). Actually, this methodologically sensitive difference was clearly reflected in the present study. Since February 2012, as both methods have been used simultaneously, 12 dogs have been found to be infected by S. stercoralis (Table 1). Only three of these infections (25\%) were detected by using the FEAST method.

Observations made by the owners and veterinarians treating the puppies infected with S. stercoralis originating from Kennel A indicate that majority of the infected dogs showed some clinical symptoms (Table 2). One puppy was abnormally small and had blood in the faeces. Another also had blood in the faeces, and five puppies had either diarrhoea (4) or soft stool (1). The signs reported in the present study seem to be in accordance with general strongyloidosis symptoms reported in the literature (Bowman 2009), i.e. that mainly puppies and young dogs are those that suffer from a blood-streaked, mucoid diarrhoea and show reduced growth rate and sometimes prominent emaciation.

S. stercoralis is clearly a threat to dog health. Therefore a careful effort should be invested on an island like Iceland, where the nematode is not indigenous, to use all available means to eradicate the parasite when found.

Dog owners and people in contact with dogs infected with with $S$. stercoralis should be informed about the zoonotic potential of the parasite (Grove 1996, Miyiazaki 1991) and the possible severity of infection in humans (Buonfrate et al. 2013). According to our knowledge there is no information that indicates that humans in contact with $S$. strongyloides infected dogs in Iceland have acquired infections from dogs.

Little (1966) reported that early first stage larvae from duodenal aspiration were 180 -240 $\mu \mathrm{m}$ long; late first stage larvae from fresh stool were 325 - $380 \mu \mathrm{m}$ long. According to Lopez et al. (2000) the length of the second stage larvae appeared to be "slightly" longer than first stage larvae. In the present study the lengh of $S$. stercoralis larvae was between 260 and $422 \mu \mathrm{m}$, indicating that the longest larvae could already have reached the second stage.

The morphological characteristics of $S$. 
stercoralis first stage larvae, including the length of the buccal canal, presence of a genital primordium and the form of the oesophagus (Figure 2), must be carefully examined in order to ensure proper identification. Examination of these characteristics are needed to differentiate S. stercoralis not only from similar parasitic nematode larvae also found in dog faeces, e.g. Ancylostoma spp. hookworms (Beaver et al. 1984, Miyazaki 1991), but also a great range of free living nematode species that are frequently found in faeces collected outdoors from the ground (Stancampiano et al. 2011, Miyazaki 1991, unpublished data).

\section{ACKNOWLEDGEMENTS}

We want to thank the officers at the Icelandic Food and Veterinary Authority, veterinarians and staff of the quarantine stations, veterinarians responsible for the household dogs, as well as the owner of breeding kennel A for providing us with various information about the dogs and anthelmintic treatments.

\section{REFERENCES}

Al-Sabi MN, Kapel CM, Johansson A, Espersen MC, Koch J \& Willesen JL 2013. A coprological investigation of gastrointestinal and cardiopulmonary parasites in hunting dogs in Denmark. Veterinary parasitology 196, 366-372.

http://dx.doi.org/10.1016/j.vetpar.2013.03.027

Allen AV \& Ridley DS 1970. Further observations on the formol-ether concentration technique for faecal parasites. Journal of Clinical Pathology 23, 545-546.

Anonymous 1947. Deettir um innflutning búfjár og karakúlsjúkdóma [Topics on import of livestock and Karakul-diseases]. Ríkisprentsmiðjan Gutenberg, Reykjavík, 296 p. [In Icelandic]

Ash L \& Orihel T 1997. Atlas of Human Parasitology, 4th edn. American Society of Clinical Pathologists. Chicago, Illinois, $410 \mathrm{p}$.

Asano K, Suzuki K, Matsumoto T, Sakai T \& Asano R 2004. Prevalence of dogs with intestinal parasites in Tochigi, Japan in 1979, 1991 and 2002. Veterinary parasitology 120, 243-248. http://dx.doi.org/10.1016/j.vetpar.2004.01.009

Assefa T, Woldemichael T \& Seyoum T 1991.
Evaluation of the modified Baermann's method in the laboratory diagnosis of Strongyloides stercoralis. Ethiopian Medical Journal 29, 193198.

Beaver PC, Jung RC, Cupp EW \& Craig CF 1984. Clinical Parasitology, 9th edn. Lea \& Febiger, Philadelphia, $825 \mathrm{p}$.

Bowman DD 2009. Helminths. In: Georgis' Parasitology for Veterinarians, 9th edn., Bowman DD (ed.). Saunders Elsevier, St. Louis, Missouri, pp. 115-239.

Bugg RJ, Robertson ID, Elliot AD \& Thompson RCA 1999. Gastrointestinal parasites of urban dogs in Perth, Western Australia. The Veterinary Journal 157, 295-301.

http://dx.doi.org/10.1053/tvj1.1998.0327

Buonfrate D, Requena-Mendez A, Angheben A, Muñoz J, Gobbi F, Van Den Ende J \& Bisoffi Z 2013. Severe strongyloidiasis: a systematic review of case reports. BMC infectious diseases 13, 1. http://dx.doi.org/10.1186/1471-2334-13-78

Buonfrate D, Formenti F, Perandin F \& Bisoffi Z 2015. Novel approaches to the diagnosis of Strongyloides stercoralis infection. Clinical Microbiology and Infection 21, 543-552.

http://dx.doi.org/10.1016/j.cmi.2015.04.001

Dawkins HJS \& Grove DI 1982. Attempts to establish infections with Strongyloides stercoralis in mice and other laboratory animals. Journal of Helminthology 56, 23-26.

Dillard KJ, Saari SA \& Anttila M 2007. Strongyloides stercoralis infection in a Finnish kennel. Acta Veterinaria Scandinavica 49, 37. http://dx.doi.org/10.1186/1751-0147-49-37

Dreyer G, Fernandes-Silva E, Alves S, Rocha A, Albuquerque R \& Addiss D 1996. Patterns of detection of Strongyloides stercoralis in stool specimens: Implications for diagnosis and clinical trials. Journal of Clinical Microbiology 34, 25692571.

Gaunt MC \& Carr AP 2011. A survey of intestinal parasites in dogs from Saskatoon, Saskatchewan. Canadian Veterinary Journal 52, 497-500.

Georgi JR \& Sprinkle CL 1974. A case of human strongyloidosis apparently contracted from asymptomatic colony dogs. The American Journal of Tropical Medicine and Hygiene 23, 899-901.

Goncalves ALR, Machado GA, Goncalves-Pires 
MRF, Ferreira-Junior A, Silva DAO \& CostaCruz JM 2007. Evaluation of strongyloidiasis in kennel dogs and keepers by parasitological and serological assays. Veterinary Parasitology 147, 132-139.

http://dx.doi.org/10.1016/j.vetpar.2007.03.016

Grove DI 1996. Human strongyloidiasis. Advances in Parasitology 38, 251-309.

http://dx.doi.org/10.1016/S0065-308X(08)60036-6

Grove DI \& Northern C 1982. Infection and immunity in dogs infected with a human strain of Strongyloides stercoralis. Transactions of the Royal Society of Tropical Medicine and Hygiene 76, 833-838.

http://dx.doi.org/10.1016/0035-9203(82)90120-1

Hamnes IS, Davidson R \& Øines Ø 2009. Strongyloides stercoralis påvist hos hund i Norge for første gang [Strongyloides stercoralis identified in dogs in Norway for the first time]. Norsk Veterincertidsskrift 121, 752. [In Norwegian].

Henriksen SA 1965. En forbedret teknik ved undersøgelser for lungeormelarver $i$ faeces. [An improved technique for the examination of faeces for larvae of lungworms]. Nordisk Veterincermedicin 17: 446-454. [In Danish].

Itoh N, Kanai K, Hori Y, Hoshi F \& Higuchi S. 2009. Prevalence of Giardia intestinalis and other zoonotic intestinal parasites in private household dogs of the Hachinohe area in Aomori prefecture, Japan in 1997, 2002 and 2007. Journal of Veterinary Science 10, 305-308.

https://doi.org/10.4142/jvs.2009.10.4.305

Itoh N, Muraoka N, Aoki M \& Itagaki T 2003. [Prevalence of Strongyloides spp. infection in household dogs]. Kansenshogaku zasshi. The Journal of the Japanese Association for Infectious Diseases 77, 430-435 [In Japanese with English abstract].

http://dx.doi.org/10.11150/kansenshogakuzasshi1970.77.430

Jones O, Kebede N, Kassa T, Tilahun G \& Macias C 2011. Prevalence of dog gastrointestinal parasites and risk perception of zoonotic infection by dog owners in Wondo Genet, Southern Ethiopia. Journal of Public Health and Epidemiology 3, 550555.

Júnior AF, Goncalves-Pires MRF, Silva DAO,
Goncalves ALR \& Costa-Cruz JM 2006. Parasitological and serological diagnosis of Strongyloides stercoralis in domesticated dogs from southeastern Brazil. Veterinary Parasitology $136,137-145$.

http://dx.doi.org/10.1016/j.vetpar.2005.10.022

Kapel CMO \& Nansen P 1996. Gastrointestinal helminths of arctic foxes (Alopex lagopus) from different bioclimatological regions in Greenland. Journal of Parasitology 82, 17-24.

http://dx.doi.org/10.2307/3284109

Krolewiecki AJ, Lammi P, Jacobson J, Gabrielli AF, Levecke B, Socias E, Arias LM, Sosa N, Abraham D, Cimino R, Echazu A, Crudi F, Vercrysse J \& Ablonico M 2013. A public health response against Strongyloides stercoralis: time to look at soil-transmitted helminthiasis in full. PLoS Neglected Tropical Diseases 7, e2165. http://dx.doi.org/10.1371/journal.pntd.0002165

Little MD 1966. Comparative morphology of six species of Strongyloides (Nematoda) and redefinition of the genus. Journal of Parasitology $52,69-84$.

http://dx.doi.org/10.2307/3276396

Lopez PM, Nolan T \& Schad GA 2000. Growth of the genital primordium as a marker to describe a time course for the heterogonic larval development in Strongyloides stercoralis. Journal of Parasitology 86, 882-883.

Miyazaki I 1991. An Illustrated Book of Helminth Zoonoses. International Medical Foundation of Japan, Tokio, $494 \mathrm{p}$.

Olsen A, van Lieshout L, Marti H, Polderman T, Polman K 2009. Strongyloidiasis - the most neglected of the neglected tropical diseases? Transactions of the Royal Society of Tropical Medicine and Hygiene 103, 967-972. http://doi: 10.1016/j.trstmh.2009.02.013

Papazahariadou M, Founta A, Papadopoulos E, Chliounakis S, Antoniadou-Sotiriadou K \& Theodorides Y 2007. Gastrointestinal parasites of shepherd and hunting dogs in the Serres Prefecture, Northern Greece. Veterinary Parasitology 148, 170-173.

http://dx.doi.org/10.1016/j.vetpar.2007.05.013

Pálsson PA 1984. Hydatidosis in Iceland: how it 
was eradicated. In: Euzeby J \& Gevrey J (eds.). Some important parasitic infections in bovines considered from economic and social (zoonosis) points of view. Parasitological Symposium, Lyons, France, 24-26 October, 1983, pp. 121-131.

Petersen S, Joensen KD, Monrad J \& Thamsborg SM 2008. Forekomst af indvoldsorm hos hunde på Færøerne. [Occurrence of intestinal parasites of dogs on the Faroe islands]. Dansk Veterincertidsskrift, 91, 28-33. [In Danish]

Razmi G 2009. Survey of Dogs' Parasites in Khorasan Razavi Province, Iran. Iranian Journal of Parasitology 4, 48-54.

Requena-Méndez A, Chiodini $P$, Bisoffi $Z$, Buonfrate D, Gotuzzo E \& Muñoz J 2013. The laboratory diagnosis and follow up of strongyloidiasis: A systematic review. PLoS Neglected Tropical Diseases 7, e2002.

http://dx.doi.org/10.1371/journal.pntd.0002002

Ramírez-Barrios RA, Barboza-Mena G, Muñoz J, Angulo-Cubillán F, Hernández E, González F \& Escalona F 2004. Prevalence of intestinal parasites in dogs under veterinary care in Maracaibo, Venezuela. Veterinary Parasitology 121, 11-20. http://dx.doi.org/10.1016/j.vetpar.2004.02.024

Richter SH \& Elmarsdóttir Á 1997. Intestinal parasites in dogs in Iceland: The past and the present. Icelandic Agricultural Sciences 11, 151158.

Richter SH, Eydal M \& Skírnisson K 1990. Sníkjudýr í mönnum á Íslandi fundin við rannsóknir á árunum 1973-1988 [Endoparasites in humans in Iceland found in studies during 19731988]. The Icelandic Medical Journal 76, 224-245. [In Icelandic with English summary].

Runólfsson H 2004. Saga embættis yfirdýralæknis [The history of the office of the chief veterinarian]. In: Sandholt B (ed.) Dýralceknatal, búfjársjúkdómar og saga. Oddi, Reykjavík, pp. 255-267. [In Icelandic].

Schär F, Trostdorf U, Giardina F, Khieu V, Muth S, Marti H, Vounatsou P \& Odermatt P 2013. Strongyloides stercoralis: Global distribution and risk factors. PLoS Neglected Tropical Diseases 7: e2288.

http://dx.doi.org/10.1371/journal.pntd.0002288
Shoop WL, Michael BF, Eary CH \& Haines HW 2002. Transmammary transmission of Strongyloides stercoralis in dogs. Journal of Parasitology 88, 536-539.

http://dx.doi.org/10.1645/0022-3395(2002)088[0536:TT OSSI]2.0.CO;2

Skírnisson K, Richter SH \& Eydal M 2003. Prevalence of human parasites in Iceland: Past and present status. In: Akuffo H, Linder E, Ljungström I \& Wahlgren M (eds.) Parasites of the Colder Climates. Taylor \& Francis, London and New York, pp. 34-44.

Stancampiano L, Morandi F, Usai F, Benazzi C \& Pietra M 2011. An unusual case of fatal Strongyloides stercoralis hyperinfection. Veterinaria 25, 39-44.

Taylor MA, Coop RL, Wall RL 2007. Veterinary Parasitology, 3rd edn. Oxford, Blackwell Publishing Ltd, $904 \mathrm{p}$.

Ugochukwu EI \& Ejimadu KN 1985. Studies on the prevalence of gastro-intestinal helminths of dogs in Calabar, Nigeria. International Journal of Zoonoses 12, 214-218.

Ugbomoiko US, Ariza L \& Heukelbach J 2008. Parasites of importance for human health in Nigerian dogs: High prevalence and limited knowledge of pet owners. BMC Veterinary Research, 4:49. http://doi:10.1186/1746-6148-4-49

Yang M, Gebeyehu EB, Jung SJ, Kwon OD \& Kwak D 2013. Treatment of naturally acquired Strongyloides stercoralis infection in a dog with icermectin. Journal of Animal and Plant Sciences 23, 337-339.

Young KH, Bullock SL, Melvin D \& Spruill CL 1979. Ethyl acetate as a substitute for diethyl ether in the formalin-ether sedimentation technique. Journal of Clinical Microbiology 10, 852-853.

Zewdu E, Semahegn Y \& Mekibib B 2010. Prevalence of helminth parasites of dogs and owners awareness about zoonotic parasites in Ambo town, central Ethiopia. Ethiopian Veterinary Journal, 14, 17-30.

http://dx.doi.org/10.4314/evj.v14i2.63881

Manuscript received 13 September 2016 Accepted 21 November 2016 